\title{
Non-Genomic Action of Androgens is Mediated by Rapid Phosphorylation and Regulation of Androgen Receptor Trafficking
}

\author{
Qiong Denga,b Zeng Zhang ${ }^{\mathrm{b}} \quad$ Yong Wu $^{\mathrm{b}} \quad$ Wang-yang Yuc Jianwen Zhang \\ Zhi-mao Jiang $^{\text {b }}$ Ying Zhang ${ }^{a}$ Hui Liang ${ }^{a}$ Yao-ting Guib
}

\begin{abstract}
aDepartment of Urology, People's Hospital of Longhua District, Shenzhen, 'Guangdong and Shenzhen Key Laboratory of Male Reproductive Medicine and Genetics, Peking University Shenzhen Hospital, Shenzhen PKU-HKUST Medical Center, Shenzhen, cPingshan New District Animal Health Inspection Institute, Shenzhen, China
\end{abstract}

\section{Key Words}

Phosphorylation • Androgen receptor • Non-genomic action

\begin{abstract}
Background: Testosterone is critical for maintaining spermatogenesis and male fertility. The accomplishment of these processes requires the synergistic actions of the classical and non-classical signaling pathways of androgens. Methods: A murine testicular Sertoli cell line, TM4 cell was used to examine androgen actions in Sertoli cells. Western blot analysis and immunofluorescence assay were employed to study the testosterone-induced Androgen receptor (AR) translocation. Protein phosphorylation antibody array was applied to identify the phosphorylation sites under testosterone treatment, and these findings were verified by Western blot analysis. Results: We found that a physiological dose of testosterone induced fast membrane association of AR. By using a phosphorylation antibody array, several phosphorylation sites, such as MEK1/2 (Ser217/221), Akt (Ser473), and Erk1/2 (Thr202/Tyr204) were rapidly phosphorylated within 5 min of testosterone treatment. Inhibition of the MEK and Akt signaling pathways prevented AR trafficking. Blocking of AR by flutamide eliminated the stimulation effect of testosterone on kinase phosphorylation. Testosterone induced kinase Src phosphorylation, and inhibition of Src restricted AR translocation to the membrane and the nucleus. Conclusion: Findings suggested that the membrane association of AR was mediated by the MEK and Akt phosphorylation signaling pathways, which resulted in Src activation and was initiated by testosterone binding to the membrane-localized AR. This study provides new insights into the testosterone signaling pathway in Sertoli cells, which mediate spermatogenesis. In addition, the study can be used in the diagnosis and treatment of male infertility caused by disorders in spermatogenesis.
\end{abstract}

Hui Liang,

and Yao-ting Gui

KARGER
Department of Urology, People's Hospital of Longhua District, and Guangdong and

Shenzhen Key Laboratory of Male Reproductive Medicine and Genetics, Peking University

Shenzhen Hospital, Shenzhen, (China); E-Mail dr.lianghui@aliyun.com, guiyaoting2007@aliyun.com 


\section{Cellular Physiology Cell Physiol Biochem 2017;43:223-236

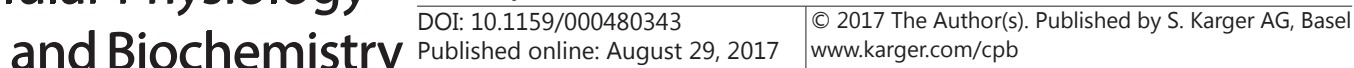 \\ Deng et al.: Phosphorylation Signaling Pathway Mediated AR Trafficking}

\section{Introduction}

Androgens are important for maintaining spermatogenesis and male fertility. Testosterone produced by the Leydig cells represents the major androgen in testis is required for at least four critical processes during spermatogenesis: maintenance of the blood-testis barrier (BTB), meiosis, Sertoli-spermatid adhesion, and sperm release [1]. Androgen effects are mediated by the androgen receptor (AR), which is $110 \mathrm{kDa}$ protein localized to the cytoplasm and the nucleus. Androgen/AR signaling in Sertoli cells plays the most important role in meiosis I during spermatogenesis, and the testis from Sertoli cell-specific AR knockout $\left(\mathrm{S}^{-} \mathrm{AR}^{-/ y}\right)$ mice shows the most detrimental phenotype in that spermatogenesis arrests predominantly at the diplotene primary spermatocyte stage before the first meiotic division [2-4]. The functional AR in germ cells is not essential for spermatogenesis and male fertility in mice [5]. The AR in the Sertoli cells of seminiferous tubules is important for spermatogenesis by indirect actions to germ cells, such as regulating DNA double-strand break repair and chromosomal synapsis of spermatocytes via intercellular epidermal growth factor (EGF)epidermal growth factor receptor (EGFR) signaling [6].

The AR can transmit testosterone signals by the classical and non-classical pathways. The AR is basically in the cytoplasm, associated with the scaffolding proteins heat shock protein 90 (HSP90), heat shock protein 70 (HSP70) [7], kinase Src, and other chaperone proteins. With elevations of circulating androgen, the steroid hormone diffuses through the cell membrane into the cytoplasm and binds to the receptor, inducing dissociation from the scaffolding proteins and translocation to the nucleus; it then binds to the androgen response element in the chromatin, inducing transcriptional activation and repression [8]. These classical genomic effects of androgens are slow and occur after several hours because they require transcription and translation of the newly synthesized protein. Some effects of androgens, such as the dynamics of tight junctions and adherens junctions [9-11], are exhibited too quickly to be explained by genomic actions; in addition, these effects have been postulated to involve non-genomic effects $[12,13]$.

AR induced by testosterone can activate the MAP kinase cascade (RAF, MEK, ERK) via Src kinase and the EGFR in Sertoli cells to enhance CREB phosphorylation [13]. Phosphorylated CREB, with other cofactor, binds to cAMP response elements (CREs) and induces gene transcription. CREB is required to produce a Sertoli cell-derived factor critical for germ cell survival. Eliminating phosphorylation of CREB causes apoptosis and elimination of germ cells [14]. Both classical and non-classical signaling pathways in Sertoli cells are necessary to support spermatogenesis. Inhibition of either pathway to Sertoli cells of mouse testes results in the destruction of the BTB which is important for spermatogenesis [15].

In the early 1980s, Hua et al. hypothesized membrane receptors mediate non-genomic effects [16]. This hypothesis was confirmed by several reports, suggesting that the membrane steroid receptors mediate the rapid action. Estradiol can interact with estrogen receptor (ER) localized to the plasma membrane and activate intracellular signaling pathways. Binding of estradiol causes additional ER translocation to the membrane [17-19]. The progesterone receptor is also reportedly localized in the plasma membrane [20, 21]. We conducted experiments to test this hypothesis in murine testicular Sertoli cell line TM4 cells. The data showed that the cytoplasmic AR was transported to the membrane and the nucleus under the 30 min treatment of the physiological concentration of testosterone $(10 \mathrm{nM})$. This finding was verified by cell immunofluorescence result. Membrane ARs transported from the cytoplasm mediated this rapid action of testosterone. On the basis of our finding, the new question regarding the mechanism mediating AR trafficking was raised.

The non-classical action of androgens was mediated by the phosphorylation signaling pathway. We then hypothesize that AR trafficking was mediated by the signaling pathway. This study can enrich the mechanism of androgen action, and provide new insights into the testosterone signaling pathway in Sertoli cells, which mediate spermatogenesis. It may also be useful for the diagnose and treatment of male infertility caused by disorders in spermatogenesis.

\section{KARGER}




\section{Cellular Physiology Cell Physiol Biochem 2017;43:223-236 \begin{tabular}{ll|l} 
DOI: 10.1159/000480343 & $\begin{array}{l}\text { O } 2017 \text { The Author(s). Published by S. Karger AG, Basel } \\
\text { www.karger.com/cpb }\end{array}$ \\
\cline { 2 - 4 } and Biochemistry
\end{tabular} \\ Deng et al.: Phosphorylation Signaling Pathway Mediated AR Trafficking}

\section{Materials and Methods}

\section{Cell Culture and Treatments}

Murine Sertoli cell line TM4 and androgen-sensitive human prostate adenocarcinoma cell line LnCaP were purchased from the American Type Culture Collection (Manassas, VA). All cells were cultured in Dulbecco's Modified Eagle's Medium (DMEM, Gibco) containing 10\% fetal bovine serum (v/v), and $100 \mu \mathrm{g} /$ $\mathrm{ml}$ penicillin and $100 \mathrm{\mu g} / \mathrm{ml}$ streptomycin at $37^{\circ} \mathrm{C}$ with atmospheric conditions of $95 \%$ air and $5 \% \mathrm{CO}_{2}$. Cells plated in 6-cm culture dishes, which reached $80 \%-85 \%$ confluence, were changed to serum-free medium containing $0.1 \%$ BSA and then incubated for 6 hours prior to testosterone exposure, as indicated in the results or Figure legends.

\section{Reagents and Antibodies}

Unless otherwise indicated, all reagents were purchased from Life Technologies (Gibco). Testosterone is dissolved in ethanol, and the vehicle for kinase inhibitors is DMSO. The antibodies used in the study are listed in Table 1.

\section{Cell Fractionation and Immunoblot Analysis}

After cells were harvested, cytoplasmic, membrane, and nuclear protein fractions were separated using the subcellular protein fractionation kit for cultured cells (Pierce, Life Technologies) as previously

Table 1. Antibodies used in the study

\begin{tabular}{|c|c|c|c|c|}
\hline Antibody & Specie & Catalog & Dilution & Source \\
\hline $\operatorname{AR}(\mathrm{N}-20)$ & $\begin{array}{c}\text { Rabbit } \\
\text { Polyclonal }\end{array}$ & sc-816 & $1: 1000$ & $\begin{array}{c}\text { Santa Cruz } \\
\text { Biotechnology }\end{array}$ \\
\hline E Cadherin & $\begin{array}{c}\text { Mouse } \\
\text { Monoclonal }\end{array}$ & ab76055 & $1: 2000$ & Abcam \\
\hline Pan Cadherin & $\begin{array}{c}\text { Mouse } \\
\text { Monoclonal }\end{array}$ & $a b 22744$ & 1: 5000 & Abcam \\
\hline HDAC1 & $\begin{array}{c}\text { Rabbit } \\
\text { Polyclonal }\end{array}$ & ab53091 & $1: 1000$ & Abcam \\
\hline GAPDH (V-18) & Goat Polyclonal & $\begin{array}{c}\text { sc- } \\
23057\end{array}$ & $1: 1000$ & $\begin{array}{c}\text { Santa Cruz } \\
\text { Biotechnology }\end{array}$ \\
\hline Phospho-Akt (Ser473) & $\begin{array}{c}\text { Rabbit } \\
\text { Monoclonal }\end{array}$ & \#4058 & $1: 1000$ & $\begin{array}{l}\text { Cell Signaling } \\
\text { Technology }\end{array}$ \\
\hline Akt (pan) & $\begin{array}{c}\text { Rabbit } \\
\text { Monoclonal }\end{array}$ & \#4685 & $1: 1000$ & $\begin{array}{l}\text { Cell Signaling } \\
\text { Technology }\end{array}$ \\
\hline $\begin{array}{l}\text { Phospho-p44/42 MAPK (Erk1/2) } \\
\text { (Thr202/Tyr204) }\end{array}$ & $\begin{array}{c}\text { Rabbit } \\
\text { Monoclonal }\end{array}$ & $\# 4370$ & $1: 1000$ & $\begin{array}{l}\text { Cell Signaling } \\
\text { Technology }\end{array}$ \\
\hline p44/42 MAPK (Erk1/2) & $\begin{array}{c}\text { Rabbit } \\
\text { Monoclonal }\end{array}$ & \#4695 & $1: 1000$ & $\begin{array}{l}\text { Cell Signaling } \\
\text { Technology }\end{array}$ \\
\hline Phospho-MEK1/2 (Ser217/221) & $\begin{array}{c}\text { Rabbit } \\
\text { Monoclonal }\end{array}$ & \#9154 & $1: 1000$ & $\begin{array}{c}\text { Cell Signaling } \\
\text { Technology }\end{array}$ \\
\hline MEK1/2 & $\begin{array}{c}\text { Rabbit } \\
\text { Monoclonal }\end{array}$ & \#8727 & $1: 1000$ & $\begin{array}{l}\text { Cell Signaling } \\
\text { Technology }\end{array}$ \\
\hline Phospho-GSK-3 $\alpha / \beta$ (Ser21/9) & $\begin{array}{c}\text { Rabbit } \\
\text { Monoclonal }\end{array}$ & \#8566 & $1: 1000$ & $\begin{array}{l}\text { Cell Signaling } \\
\text { Technology }\end{array}$ \\
\hline GSK- $3 \alpha / \beta$ & $\begin{array}{c}\text { Rabbit } \\
\text { Monoclonal }\end{array}$ & \#5676 & $1: 1000$ & $\begin{array}{l}\text { Cell Signaling } \\
\text { Technology }\end{array}$ \\
\hline Phospho-p70 S6 Kinase (Thr421/Ser424) & $\begin{array}{c}\text { Rabbit } \\
\text { Polyclonal }\end{array}$ & \#9204 & $1: 1000$ & $\begin{array}{c}\text { Cell Signaling } \\
\text { Technology }\end{array}$ \\
\hline p70 S6 Kinase & $\begin{array}{c}\text { Rabbit } \\
\text { Monoclonal }\end{array}$ & $\# 2708$ & 1: 1000 & $\begin{array}{c}\text { Cell Signaling } \\
\text { Technology }\end{array}$ \\
\hline$\beta$-ACTIN & $\begin{array}{c}\text { Mouse } \\
\text { Monoclonal }\end{array}$ & $\begin{array}{c}\text { sc- } \\
47778\end{array}$ & $1: 1000$ & $\begin{array}{c}\text { Santa Cruz } \\
\text { Biotechnology }\end{array}$ \\
\hline Phospho-Src Family (Tyr416) & $\begin{array}{c}\text { Rabbit } \\
\text { Monoclonal }\end{array}$ & \#6943 & 1: 1000 & $\begin{array}{c}\text { Cell Signaling } \\
\text { Technology }\end{array}$ \\
\hline Src & $\begin{array}{c}\text { Rabbit } \\
\text { Monoclonal }\end{array}$ & \#2109 & $1: 1000$ & $\begin{array}{c}\text { Cell Signaling } \\
\text { Technology }\end{array}$ \\
\hline
\end{tabular}




\section{Cellular Physiology Cell Physiol Biochem 2017;43:223-236 \\ \begin{tabular}{ll|l} 
DOI: 10.1159/000480343 29,2017 & $\begin{array}{l}\text { O 2017 The Author(s). Published by S. Karger AG, Basel } \\
\text { www.karger.com/cpb }\end{array}$
\end{tabular} \\ Deng et al.: Phosphorylation Signaling Pathway Mediated AR Trafficking}

described [22]. Protein concentrations were determined by the bicinchoninic acid protein assay. Levels of AR were measured using $20 \mu \mathrm{g}$ of protein with an anti-AR antibody (N-20; Santa Cruz Biotechnology) at 1:1000 dilution. The membranes were washed for $5 \mathrm{~min}$ with Tris-buffered saline (TBS) and $0.2 \%$ Tween 20 , repeated 3 times. Subsequently, the membranes were incubated at room temperature for $1 \mathrm{~h}$, with the secondary antibody in $5 \%$ nonfat dry milk in TBS and $0.2 \%$ Tween 20 . The specific complexes were detected using the enhanced chemiluminescence system from GE Healthcare. After exposure, the blots were striped and assayed for histone deacetylase 1 (ab53091, Abcam, 1: 1000) in the nucleus, pan-cadherin (ab22744, Abcam, 1: 5000) for the membrane, and glycerol glyceraldehyde-3-phosphate dehydrogenase (GAPDH; V-18; Santa Cruz Biotechnology) for the cytoplasm as loading controls.

\section{Immunofluorescence}

TM4 cells plated on coverslips were pre-incubated in medium supplemented with stripped serum overnight. Cells were then washed and incubated in medium with $0.1 \%$ BSA before addition of testosterone at $10 \mathrm{nM}$. After 30 minute incubation, cells were fixed for $15 \mathrm{~min}$ with $4 \%$ formaldehyde, washed with PBS, treated $2 \times 5$ min with $30 \mathrm{mM}$ glycine to quench fixation, and washed again with PBS. The coverslips were blocked using 5\% bovine serum albumin (Sigma-Aldrich), incubated with primary anti-AR (ab74272, Abcam) antibody overnight, rinsed and incubated with secondary antibody (1:500, Thermo Fisher) for 2 $\mathrm{h}$ at room temperature. The slides were then rinsed in PBS for $3 \times 5 \mathrm{~min}$, and incubated for $5 \mathrm{~min}$ at room temperature with Hoechst 33342 (1:5000, Thermo Fisher). Cells were washed with PBS for $3 \times 5$ min again, and then mounted with Prolong Gold Anti-fade Reagent (Thermo Fisher) for imaging.

\section{Statistical Analysis}

Data are presented as mean \pm SEM of the values obtained in the number of observations indicated in the text and Figure legends. The statistical analysis was conducted by using SigmaPlot. The statistical significance of the differences between groups was determined using an independent $t$ test or one/two-way ANOVA followed by protected Fisher's least significant difference post hoc test, as specified in the Figure legends. Statistical significance was set at $P<.05$.

\section{Results}

Testosterone induces association of AR to membrane proteins

To determine whether the non-genomic action of androgen involves AR association to the membrane, Western blot analysis was conducted on subcellular protein fractions of TM4 and LnCaP cells. Both cell lines expressed endogenous AR, as indicated on the western blot by a $110-\mathrm{kDa}$ band corresponding to the molecular weight of the AR (Fig. 1A). As expected, exposure to $10 \mathrm{nM}$ testosterone for $30 \mathrm{~min}$ increased the AR in the nucleus by $2.56 \pm 0.02$-fold (Fig. 1B, $P<.01$ ). A band corresponding to the AR was also observed in membrane protein fractions co-localized with pan-cadherin. One-way ANOVA also indicated the significant effect of testosterone on AR levels in the membrane protein $(\mathrm{F}=1280, P<.01)$.

As shown by the time-course and dose-response studies on the effect of testosterone on membrane AR content in Fig. 1C and Fig. 2, AR immunoreactivity in membrane proteins rapidly increased after exposure to testosterone, which became significant at the 5-min time point (1.20 \pm 0.02 -fold of the basal values, $P<.05$, Figure 2). Similar changes in AR during androgen exposure were observed in nuclear proteins (Fig. 1C).

To confirm the results of Western blot analysis, we used a confocal microscope to visualize the TM4 cells. As shown in Fig. 1D, under basal conditions, AR fluorescence was present predominantly in the cytoplasm. Consistent with the Western blot results, after incubation with $10 \mathrm{nM}$ testosterone for $30 \mathrm{~min}$, fluorescence was also observed both in the nucleus and in the membrane.

\section{Identification of phosphorylated kinases by PathScan ${ }^{\circledR}$ Signaling Antibody Array}

To understand the molecular mechanism of AR trafficking, we employed the TM4 cell line, derived from murine testicular Sertoli cells. Owing to the potential involvement of the protein phosphorylation signaling pathway in the non-classical pathway of androgens, we have adopted a systemic approach to analysis in order to identify the corresponding phos- 
Fig. 1. Testos terone induces AR association to membrane proteins. A, Western blot analysis of AR in cytoplasmic, membrane and nuclear proteins from the cells (TM4 and LnCaP) incubated for $30 \mathrm{~min}$ with vehicle (C, basal) or 10 nM testosterone (T). B, Semi-quantitative analysis of AR in the subcellular fractions after expo-

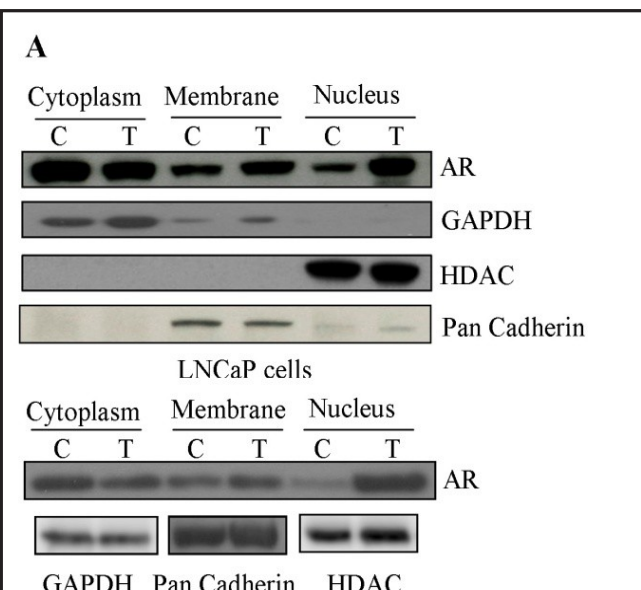

GAPDH Pan Cadherin HDAC

C

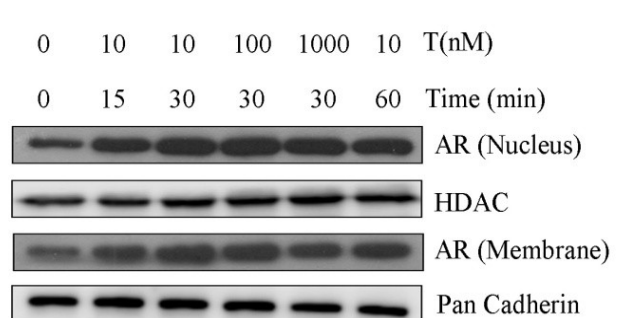

B

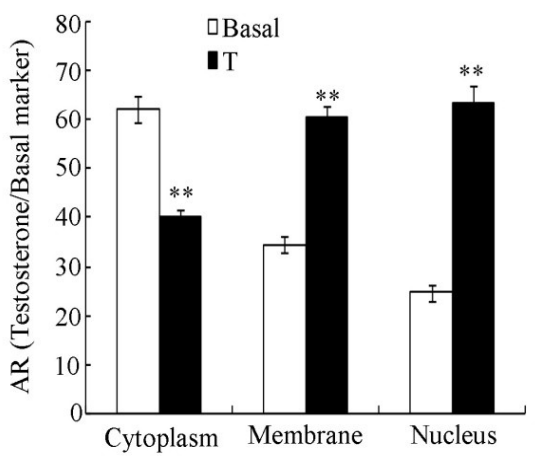

D

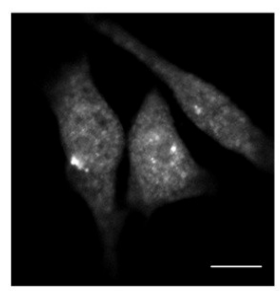

Basal

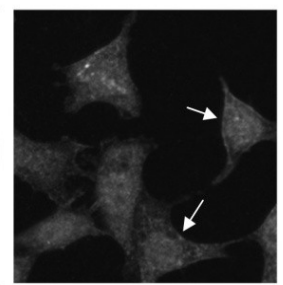

$\mathrm{T}(10 \mathrm{nM}, 30 \mathrm{~min})$

sure of TM4 cells to vehicle (basal, ethanol) or testosterone for $30 \mathrm{~min}$. Data are expressed as the mean and SEM of the ODs of the AR band multiplied by the testosterone to basal ratio of the respective marker protein, histone deacelylase (HDAC), GAPDH, and pan cadherin for nuclear, cytoplasmic and membrane fractions. $* *, \mathrm{P}<.01$ higher than the respective basal $(\mathrm{n}=5) . \mathrm{C}$, Representative western blots showing time course and dose-response of the effect of testosterone on association of AR to nucleus and membrane proteins. D, Confocal microscopy imaging of the effect of testosterone on AR trafficking. Cells were incubated with $10 \mathrm{nM}$ testosterone for 30 minutes, before fixation and confocal microscopy examination. Bar $=50 \mu \mathrm{m}$.

Fig. 2. The time course of the effect of testosterone on association of AR to nucleus and membrane proteins. A, The representative Western blots showed the time course of the effect of $10 \mathrm{nM}$ testosterone on AR trafficking. B, Semi-quantitative analysis of AR in the membrane fractions after exposure of TM4 cells to vehicle (basal, ethanol) or testosterone from 5 to $60 \mathrm{~min}$. Data are expressed as the mean and SEM of the ODs of the AR band multiplied by the testosterone to basal ratio of pan cadherin. ${ }^{* *}, \mathrm{P}<.01$; *, $\mathrm{P}<$ .05 higher than basal $(n=3)$.

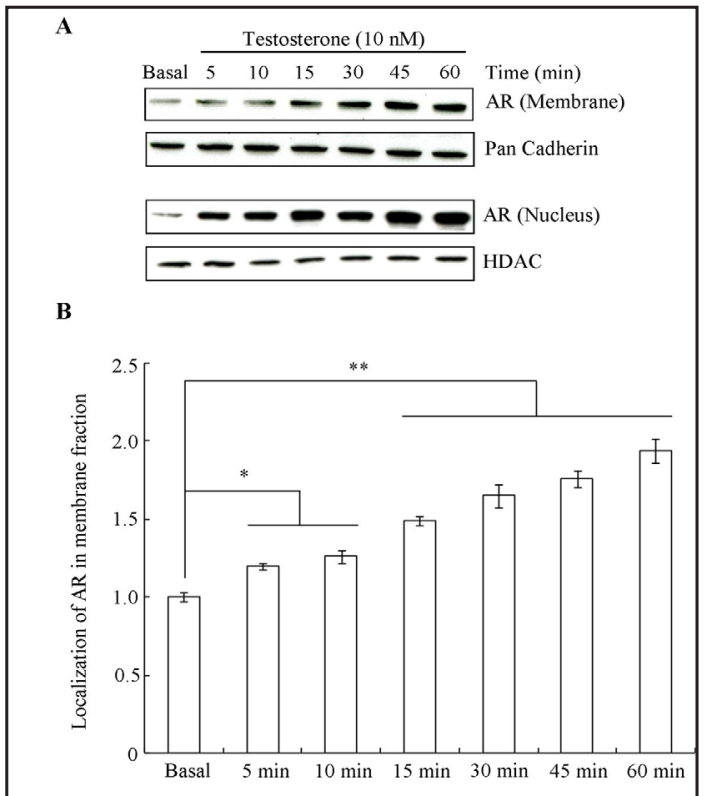


Fig. 3. Identification of phosphorylated protein kinases induced by testosterone. MEK1/2 (Ser217), MEK1/2 (Ser217/221), Akt (Ser473) and Erk1/2 (Thr202/Tyr204) were found fast phosphorylated in 5 minutes by EGFR Signaling Antibody Array. The phosphorylation levels of these sites fall back to basal levels after 10 minutes treatment of physiological testosterone $(10 \mathrm{nM})$. Akt (Ser473), GSK-3 $\alpha$ (Ser21), GSK-3 $\beta$ (Ser9), p70 S6 Kinase (Thr421/Ser424) and Erk1/2 (Thr202/ Tyr204) were found fast phosphorylated in 5 minutes by AKT Signaling Antibody Array. Akt

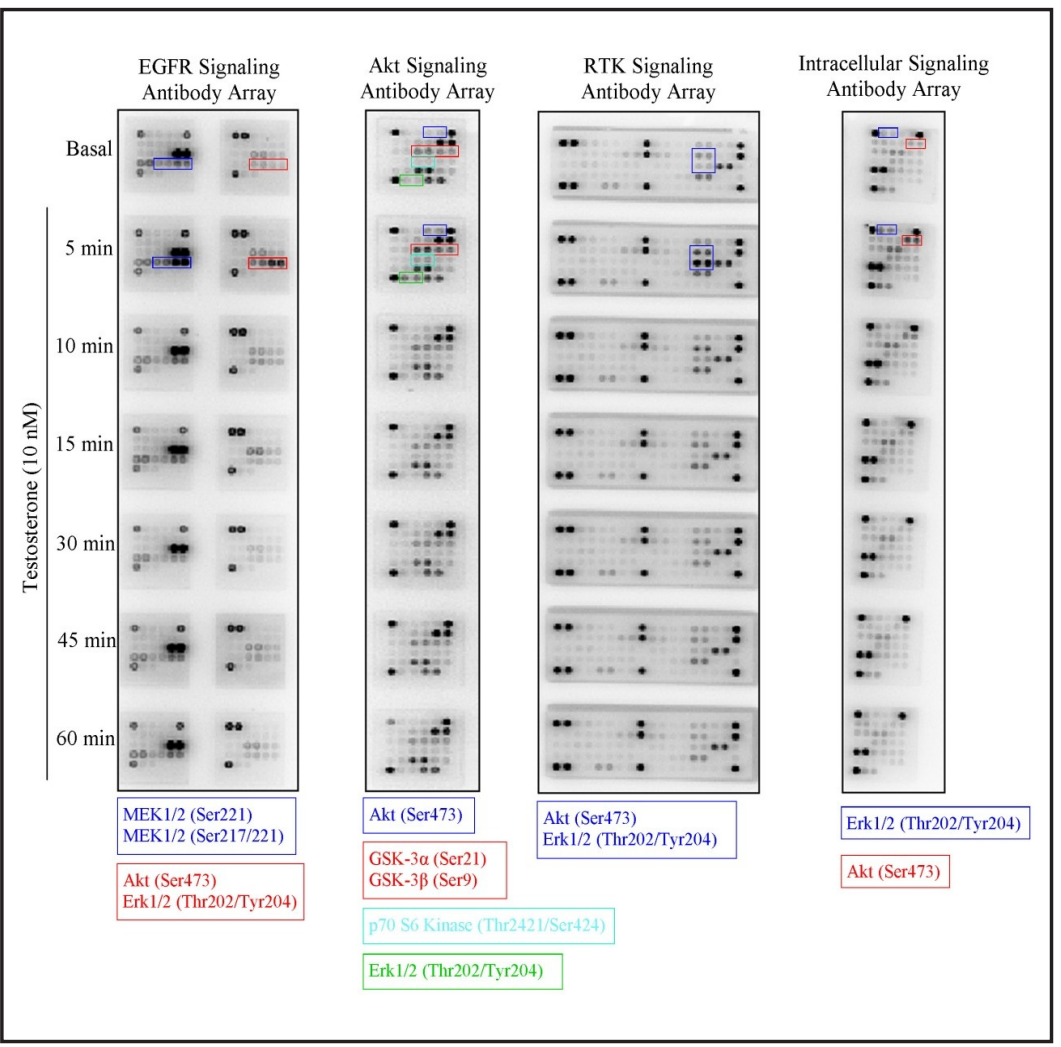
(Ser473) and Erk1/2 (Thr202/Tyr204) were rapidly phosphorylated within 5 min by using RTK Signaling Antibody Array and Intracellular Signaling Antibody Array.

Fig. 4. Verification of phosphorylation sites by Western blot analysis in TM4 cells. Representative western blot shown time course of the effect of testosterone on the phosphorylation levels of the identified kinases, this experiment was repeated for three times.

phorylated kinase in AR trafficking by using PathScan Antibody Array from Cell Signaling Technology. This polyvinylidene difluoride membrane-based array consist of spots in duplicates, and the spots corresponding to phosphorylation sites and kinase are provided by the manufacturer. We conducted the screening in accordance with the protocol, and a chemiluminescence detection system was used to capture the image.

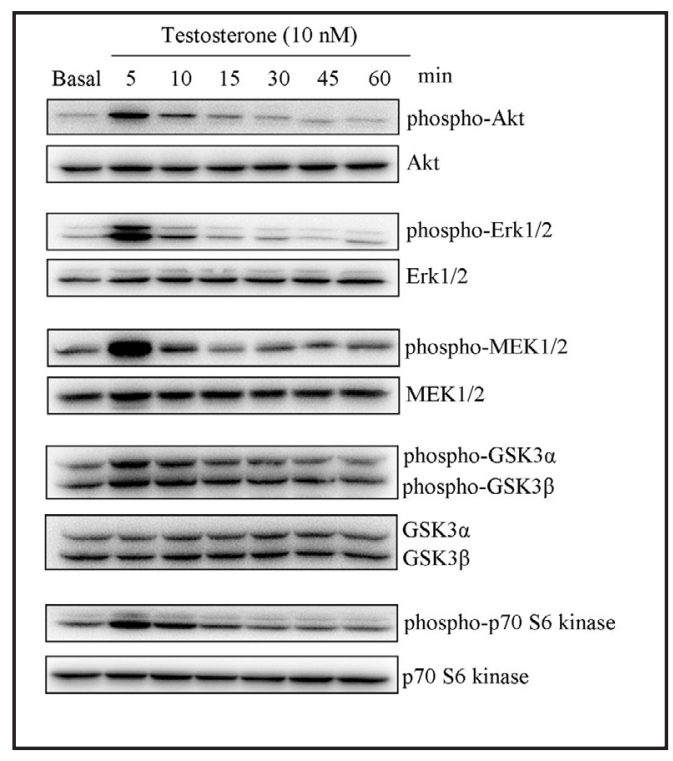

As shown in Fig. 3, 4 phosphorylation sites, including MEK1/2 (Ser217), MEK1/2 (Ser217/221), Akt (Ser473), and Erk1/2 (Thr202/Tyr204) were rapidly phosphorylated in 5 min in EGFR Signaling Antibody Array. In addition to Akt (Ser473) and Erk1/2 (Thr202/ Tyr204), 3 other phosphorylation sites-GSK-3 $\alpha$ (Ser21), GSK-3 $\beta$ (Ser9), p70 S6 kinase (Thr421/Ser424)- were also found fast phosphorylated in AKT Signaling Antibody Array. The phosphorylation levels of all phosphorylation sites decrease thereafter. The phosphorylation 


\section{Cellular Physiology Cell Physiol Biochem 2017;43:223-236

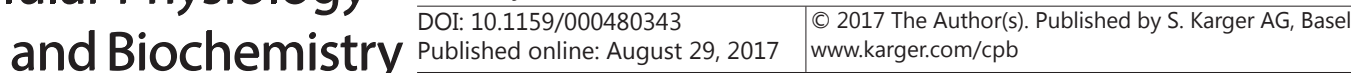

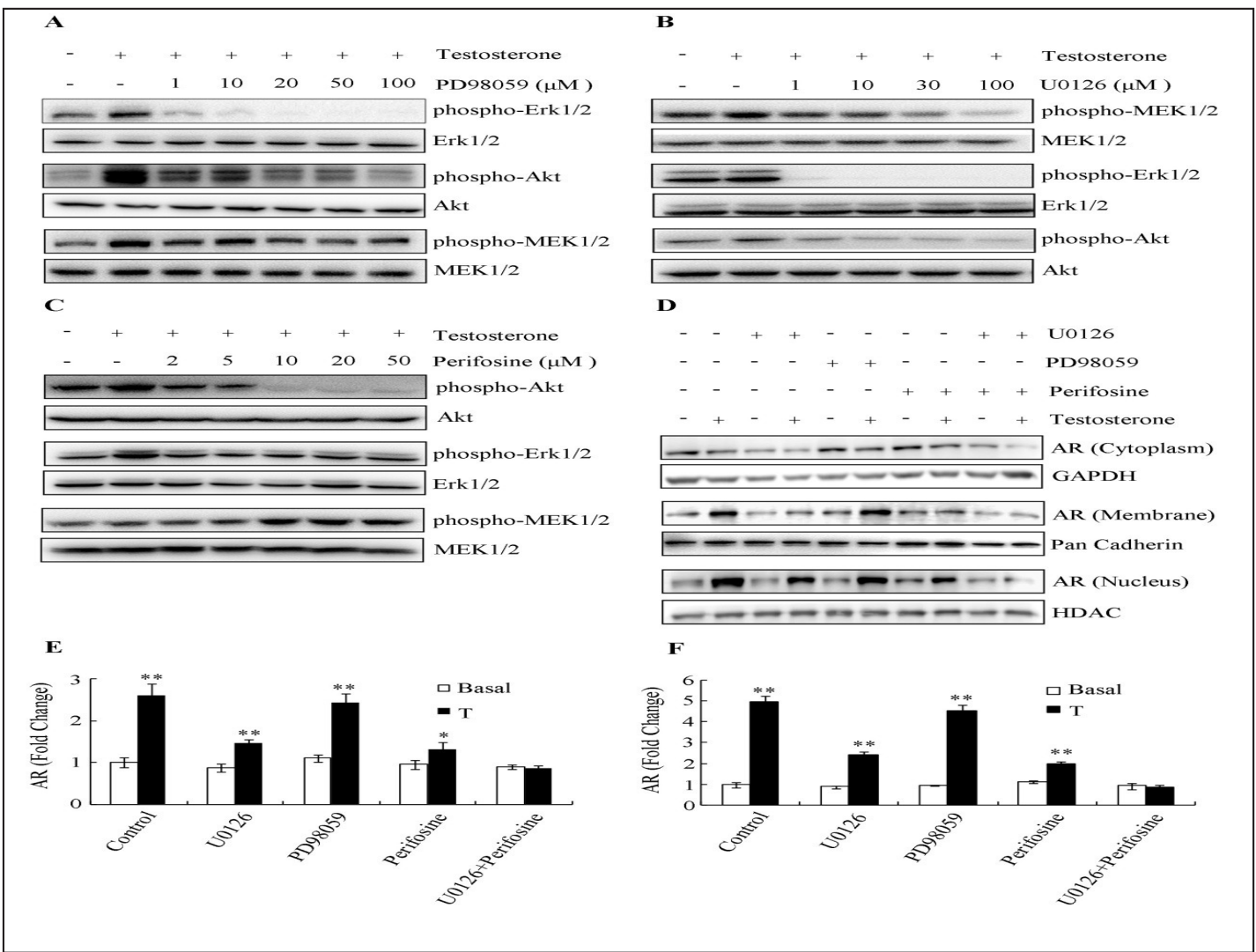

Fig. 5. Kinase inhibitors prevent AR trafficking. A, Cells were pre-incubated with Erk1/2 inhibitor, PD98059 for 2 hours before testosterone adding. Representative western blot analysis shown that $10 \mu$ M PD98059 blocked the phosphorylation of Erk1/2, and it also slightly inhibited the phosphorylation of MEK1/2 and Akt. B, MEK1/2 inhibitor, U0126 prevents MEK1/2 phosphorylation at the concentration of $100 \mu \mathrm{M}$. $\mathrm{C}$, Perifosine, Akt inhibitor inhibits Akt phosphorylation at the concentration of $10 \mu \mathrm{M}$. The inhibition of Akt phosphorylation will compensatory increase MEK1/2 phosphorylation. D, Representative western blot analysis shown that either of the MEK1/2 and Akt inhibitor blocks AR trafficking under testosterone treatment. PD98059, the Erk1/2 inhibitor, has no effect on AR trafficking. E-F, Semi-quantitative analysis of AR levels in the membrane and nuclear fractions from cells pre-incubated with kinases inhibitors. Cells received testosterone stimulation for $5 \mathrm{~min}$. Data are expressed as the mean and SEM of the ODs of the AR band multiplied by the testosterone-to-basal ratio of the respective marker protein, histone deacelylase (HDAC), and pan-cadherin for nuclear and membrane fractions, respectively. ${ }^{* *}, \mathrm{P}<.01 ;{ }^{*}, \mathrm{P}<.05(\mathrm{n}=3)$.

levels of the identified sites after testosterone exposure for $15 \mathrm{~min}$ of showed no difference from the basal levels. This result was verified by 2 more signaling pathway antibody array (Fig. 3).

The identification data of the arrays were verified by Western blot analysis in TM4 cells (Fig. 4). Cells were incubated in serum-free medium (0.1\% BSA in DMEM basic medium) for $6 \mathrm{~h}$ prior to testosterone treatment. Western blot analysis indicated the time-course of the effects of testosterone on the identified phosphorylated kinases. Physiological concentration of testosterone increased the phosphorylation of all identified sites by $5 \mathrm{~min}$, and the phosphorylation levels reached maximum within $5 \mathrm{~min}$. The values returned to their basal levels when testosterone exposure was extended.

\section{Kinase inhibitors prevent testosterone-induced AR trafficking}

To examine the relationship between AR trafficking and the phosphorylation signaling pathway, inhibitors of identified kinases were used in the study. Cells were pre-incubated 


\section{Cellular Physiology Cell Physiol Biochem 2017;43:223-236 \begin{tabular}{ll|l} 
and Biochemistry Published onlIne: August 29, 2017 & $\begin{array}{l}\text { (c) } 2017 \text { The Author(s). Published by S. Karger AG, Basel } \\
\text { www.karger.com/cpb }\end{array}$
\end{tabular}}

Fig. 6. AR antagonist flutamide prevents phosphorylation of identified kinases. A, Cells were pre-incubated with the AR antagonist flutamide in a serum-free medium with $0.1 \%$ BSA for $6 \mathrm{~h}$. Cells then received a constant stimulation of testosterone for $30 \mathrm{~min}$. Cytoplasmic, membrane, and nuclear protein fractions were separated using a subcellular protein fractionation kit for cultured cells (Pierce, Life Technologies) as previously described before. Representative Western blot analysis shows that $100 \mu \mathrm{M}$ flutamide can inhibit classical AR nuclear transport and lower concentration, $30 \mu \mathrm{M}$ flutamide significantly prevented AR membrane association $(n=3)$. B, The effect of flutamide on AR localization in membrane and nuclear fraction at basal condition. C, Cells pre-incubated with flutamide were treated with testosterone for 5 min. The whole cell fraction was extracted using a cell lysis buffer from Cell Signaling Technology (9803S). Representative Western blot analysis indicates that both $30 \mu \mathrm{M}$ and $100 \mu \mathrm{M}$ flutamide decreased the phosphorylation levels of kinase Akt, Erk1/2 and MEK1/2 (n = 3).

Fig. 7. Protein kinase Src involved in regulating AR trafficking. A, Western blots analysis using input and co-IP samples showed the association of Src with AR. B, Representative Western blot analysis indicates the time course of the effect of testosterone on kinase Src phosphorylation ( $\mathrm{n}=$ 3). Src phosphorylation levels started to increase at $5 \mathrm{~min}$ and reached the maximum at $30 \mathrm{~min}$. C, Representative Western blot analysis shows the effects of kinase inhibitors on Src phosphorylation $(n=3)$. Cells were pre-incubated with the inhibitors as mentioned previously, and then treated with the physiological testosterone concentration (10 $\mathrm{nM})$ for $5 \mathrm{~min}$. D, Src inhibitor (PP1) affects the AR membrane and nuclear trafficking in TM4 cells $(\mathrm{n}=3)$.
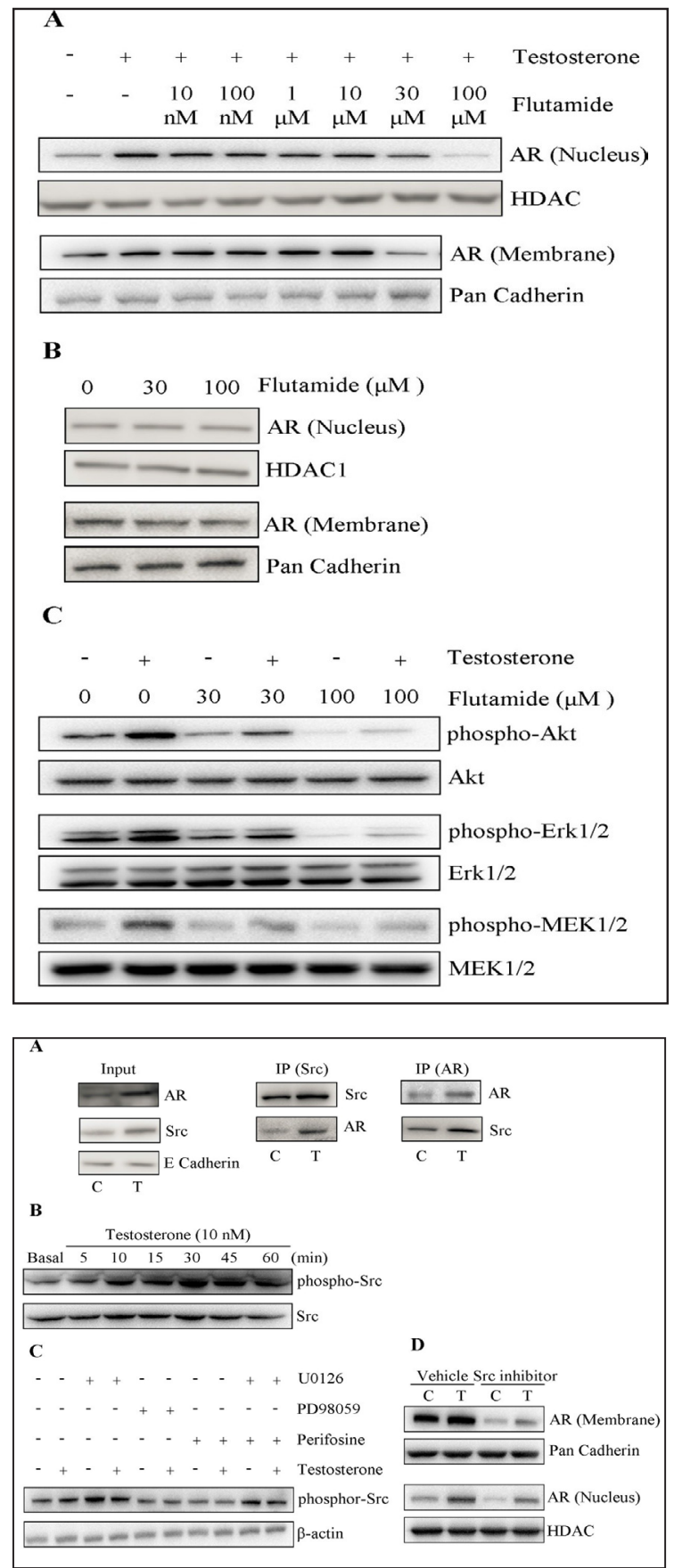

with inhibitors (PD98059 of Erk1/2 for $2 \mathrm{~h}$, U0126 of MEK1/2 for $1 \mathrm{~h}$, and perifosine of Akt for $6 \mathrm{~h}$ ) in $0.1 \%$ BSA prior to testosterone treatment (10 nM, $5 \mathrm{~min}$ ). As shown in Fig. 5A, PD98059 at $10 \mu \mathrm{M}$ completely blocked Erk1/2 phosphorylation, and slightly inhibited MEK1/2 and Akt phosphorylation. Only $100 \mu \mathrm{M}$ U0126 was able to completely eliminate MEK1/2 phosphorylation, in addition, $10 \mu \mathrm{M}$ U0126 and $1 \mu \mathrm{M}$ U0126 completely inhibited Akt and Erk1/2 phosphorylation, respectively. Perifosine at $10 \mu \mathrm{M}$ blocked Akt phosphorylation. Notably, perifosine at $10 \mu \mathrm{M}$ and higher concentrations increased MEK1/2 phosphorylation.

To evaluate the effect of the inhibitors on AR trafficking, cells were pre-incubated with inhibitors as described in previous experiments. Subsequently, cells received a stimulus of 
Fig. 8. Effect of inhibitors on kinase phosphorylation. This Fig. shows the effects of inhibitors on the phosphorylation levels of kinases, which are the downstream kinases of Akt signaling pathway. The representative bolts indicate that U0126 decreased the phosphorylation of kinase PRAS40, GSK- $3 \alpha$ and $3 \beta$, p70 S6 kinase, and S6 kinase protein. Both PD98059 and perifosine inhibited kinase PRAS40; however, the latter inhibitor potentiated the phosphorylation of the p70 S6 kinase. These blots also verified the effective inhibition on kinase (Akt, MEK, and ERK) by the corresponding inhibitors.

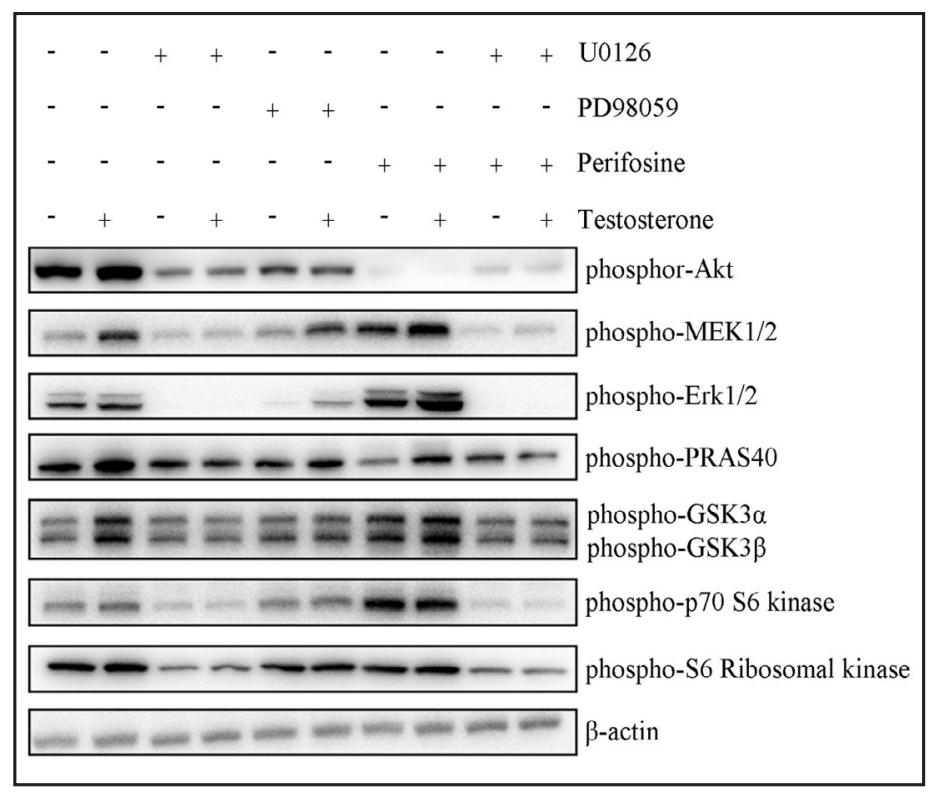

$10 \mathrm{nM}$ testosterone for $5 \mathrm{~min}$. Cytoplasmic, membrane, and nuclear fractions were separated in accordance with the previously described protocol. Representative Western blot analysis in Fig. 5D shows that either the MEK1/2 or the Akt inhibitor blocks AR translocation to the membrane and the nucleus; the combination of the MEK1/2 and Akt inhibitors completely prevented AR trafficking under testosterone treatment. PD98059, the Erk1/2 inhibitor, exerted no effect on AR trafficking.

The phosphorylation signaling pathway was mediated by $A R$

To determine whether the phosphorylation signaling pathway was mediated by AR, the AR antagonist-flutamide was used to block the association between testosterone and the AR in the study. Cells were pre-incubated with flutamide for $6 \mathrm{~h}$ prior to testosterone treatment. Protein fractions were extracted in accordance with the manufacturer's instructions described in Methods. As shown in Fig. 6A, $100 \mu \mathrm{M}$ flutamide significantly inhibited nuclear trafficking, and $30 \mu \mathrm{M}$ flutamide prevented membrane transport. And both of the concentrations did not affect AR membrane and nuclear localization at basal condition (Fig. 6B). Flutamide was then used in the study of the phosphorylation signaling pathway. The results of the Western blots analysis in Fig. 6C showed that both $30 \mu \mathrm{M}$ and $100 \mu \mathrm{M}$ AR antagonist inhibited the phosphorylation of kinases Akt, Erk1/2, and MEK1/2.

\section{Protein Kinase Src is involved in testosterone-induced AR trafficking}

In basal conditions, protein kinase Src was associated with the AR and formed a stable protein complex in the cytoplasm. The co-IP experiment verified the association of Src with AR (Fig. 7A). Src was supposed to participate in the androgen action. Representative Western blot analysis (Fig. 7B) revealed the time-course effects of testosterone on Src phosphorylation. The Src phosphorylation level was increased by physiological testosterone exposure for $5 \mathrm{~min}$; when the exposure was extended to $30 \mathrm{~min}$, the Src phosphorylation level almost reached the maximum. The fold change of Src phosphorylation is in accordance with the AR membrane translocation. Western blot analysis results (Fig. 7C) using proteins from cells pre-incubated with kinase inhibitors showed that U0126 increased Src phosphorylation, whereas perifosine and PD98059 decreased Src phosphorylation. To evulate the effect of Src kinase on AR trafficking in TM4 cells, cells were pre-incubated with the Src inhibitor PP1 (Sigma Aldrich, USA) for $2 \mathrm{~h}$ prior to a 30 min testosterone treatment. PP1 at $100 \mu \mathrm{M}$, which was demonstrated to efficiently inhibit Src phosphorylation (data not shown), significantly prevented membrane translocation and inhibited nucleus trafficking (Fig. 7D).

\section{KARGER}




\section{Cellular Physiology Cell Physiol Biochem 2017;43:223-236 \\ \begin{tabular}{ll|l} 
and Biochemistry Publisned ontIne: August 29, 2017 & $\begin{array}{l}\text { (c) } 2017 \text { The Author(s). Published by S. Karger AG, Basel } \\
\text { www.karger.com/cpb }\end{array}$ \\
\hline
\end{tabular} \\ Deng et al.: Phosphorylation Signaling Pathway Mediated AR Trafficking}

\section{Discussion}

Testosterone is essential for maintaining spermatogenesis and male fertility. However, the molecular mechanisms by which testosterone acts remain undetermined. With advances obtained from using transgenic mice that lack or express AR, cell-specific targets of testosterone action, as well as genes and signaling pathways regulated by testosterone, have been identified [1]. Testosterone acts through the AR in the somatic Sertoli cells to induce the production of factors that are required to support the maturation of adjacent germ cells into spermatozoa [23]. AR is the only specific receptor for androgen that has been identified, and at least two mechanisms underlie testosterone action through the AR: the classical and the non-classical pathways. The classical pathway is distinguished by the time required to produce a functional response. At least 30-45 min was required to induce transcriptional activation and repression after testosterone stimulation, with additional time required for protein synthesis and secretion in the cell [24].

In contrast to classical signaling, non-classical (non-genomic) testosterone signaling translates signals into alterations in cellular functions within seconds to minutes. Western blot and immunofluorescence analysis indicated rapid AR membrane trafficking under 10 $\mathrm{nM}$ testosterone treatment within $15 \mathrm{~min}$. This finding suggested that the physiological testosterone levels similar to or lower than those found in the testes could cause the AR in the cytoplasm to translocate to the plasma membrane. A new problem arose from the mechanism mediating AR trafficking in the cell, and experiments were designed to address the problem.

Binding of testosterone to AR allows the receptor to interact with and activate Src tyrosine kinase. Once activated, Src led to EGFR phosphorylation via an intracellular signaling pathway [1]. Phosphorylated pathway antibody arrays were employed to explore and verify the kinases and signaling pathways involved in non-genomic actions. As shown in Fig. 3 and Fig. 4, several phosphorylation sites, including Akt (Ser473), Erk1/2 (Thr202/Tyr204), and MEK1/2 (Ser217/221), were found to be rapid phosphorylated with 5 min exposure to physiological testosterone. This result agrees with the finding that rapid actions of the nongenomic pathway included increased phosphorylation of ERK and CREB within 1 min [13, 25]. The phosphorylation levels of the identified kinase markedly decreased and returned to basal levels within another 10-min period. Activation of kinases in the Sertoli cells is important for maintaining spermatogenesis. The correlation of kinases phosphorylation and AR trafficking was investigated in further experiments.

U0126, perifosine and PD98059 are widely known inhibitors for MEK1/2, Akt and Erk1/2, respectively. Inhibition of Akt promotes MEK1/2 phosphorylation, whereas U0126 slightly inhibits Akt phosphorylation and completely inhibits on Erk1/2 phosphorylation. These data suggest a coordinate relationship between MEK1/2 and the Akt phosphorylation signaling pathway. The Erk1/2 inhibitor PD98059 exerts no effect on AR trafficking. Nevertheless, either U0126 or perifosine significantly blocked AR membrane trafficking and nuclear translocation, and the combination of the two inhibitors completely prevented AR transport. These findings indicate that AR trafficking under testosterone stimulation was mediated by the MEKand Akt phosphorylation pathways. In addition, the inhibition of nucleus translocation suggested that kinases activation by the non-genomic signaling in Sertoli cells can result in the regulation of AR-mediated nuclear (genomic) gene transcription. We also detected the phosphorylation levels of the kinases, which were highly phosphorylated or rapidly phosphorylated, in the cells pre-incubated with the inhibitors. These data presented in Fig. 8. As expected, obvious inhibitory effects on the corresponding kinases were observed. The MEK inhibitor U0126 decreased the phosphorylation of kinase PRAS40, GSK-3 $\alpha$ and $3 \beta$, p70 S6 kinase, and S6 kinase protein. Both PD98059 and perifosine inhibited kinase PRAS40; however, the latter inhibitor potentiated the phosphorylation of p70 S6 kinase.

Two receptors were supposed to be involved in the testosterone non-genomic signaling pathway, classical AR, and G protein-coupled receptor. To determine the receptor mediating the rapid phosphorylation signaling pathway, we used flutamide, a selective antagonist of 
Fig. 9. Testosterone signaling pathway in Sertoli cells. Left (pathway 1): the classical testosterone signaling pathway: testosterone diffuses through the plasma membrane and binds with the $\mathrm{AR}$, then translocates to the nucleus where it binds to specific DNA sequences AREs. Right (pathway 2): the non-classical MAP kinase activation pathway: testosterone interacts with membrane AR that is then able to bind with and activate Src. Src causes the activation of the EGFR that then activates the MAP kinase cascade most likely through Ras resulting in the sequential phosphorylation and activation of RAF and MEK and

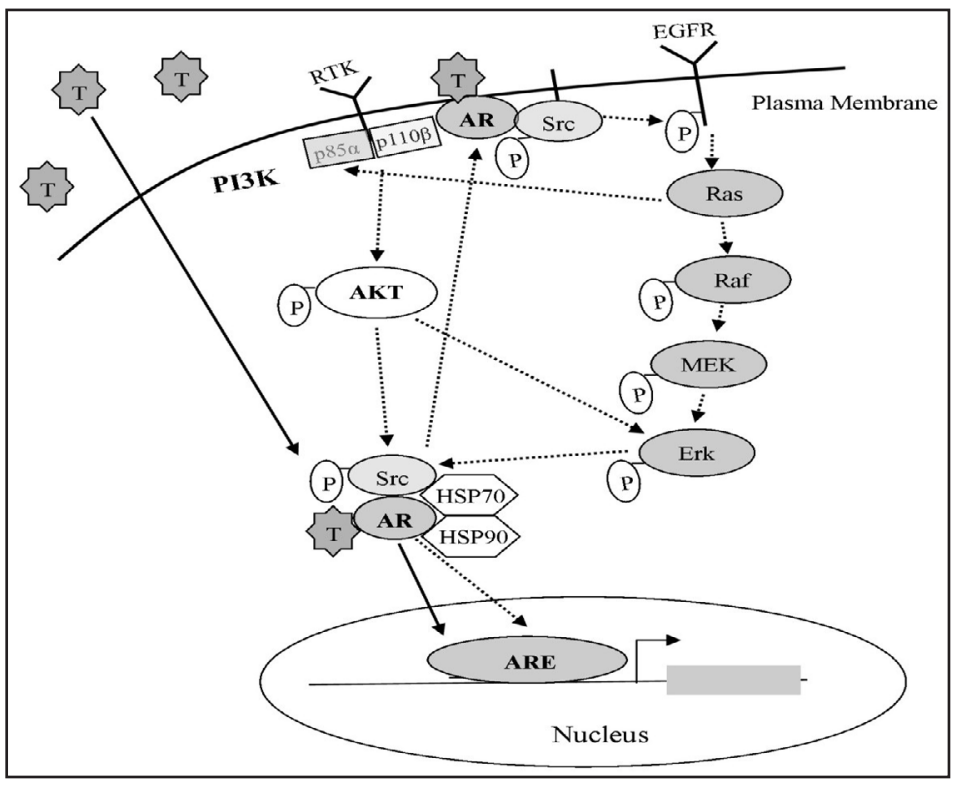
then Erk. Middle (pathway 3): the non-classical PI3K/AKT pathway: AR could direct interact with PI3K regulatory subunit p85 $\alpha$, and Ras could interact with PI3K catalytic subunit p110 $\beta$ to activate PI3K, resulted in the activation of kinase AKT. These two non-genomic pathways can led to the activation of kinase $\mathrm{Src}$, and then regulate AR translocation to the plasma membrane and the nucleus. The phosphorylation signaling pathway is denoted by a dotted line with an arrow; the classical AR signaling pathway is denoted by a black arrow.

the AR competing with androgens such as testosterone. Flutamide prevented AR membrane and nuclear trafficking, as well as inhibited kinases phosphorylation. This effect suggests that the phosphorylation signaling pathway was initiated by the androgens binding to the classical AR. We also conducted experiments to study the effect of testosterone on AR phosphorylation, and the blots showed that there was no significantly difference of AR phosphorylation (Ser 210, and Ser 213) after exposure to $10 \mathrm{nM}$ testosterone for up to $1 \mathrm{~h}$ (data not shown).

The non-receptor tyrosine kinase Src is regarded as a major factor in signal transduction $[18,19,26-29]$. The release of mature sperm from Sertoli cells is regulated by Src kinase family members [30-32] that can be activated by non-genomic signaling [12]. Src is also known to phosphorylate FAK, $\beta$-catenin and $\mathrm{N}$-cadherin proteins that contribute to the formation of adhesion complexes between Sertoli cells and the mature elongated spermatids [33-35]. There is a report that membrane androgen receptor down-regulates c-Src-activity and $\beta$-catenin transcription and triggers GSK-3beta-phosphorylation in colon tumor cells [36]. Culturing seminiferous tubule fragments in the presence of an Src kinase inhibitor decreased the relative number of sperm released. Src kinase basically interacts with the cytoplasmic AR and then forms a stable complex. A report demonstrated that targeting Src kinase decreased AR nuclear translocation and nuclear distribution [37]. Consistent with the reports described above, the representative blot data showed that testosterone increased Src phosphorylation within 5 minutes (Fig. 7B). Inhibition of the MEK or Akt signaling pathway would change the phosphorylation status of kinase Src (Fig. 7C), and the inhibition of Src family by PP1 $(100 \mu \mathrm{M})$ decreased the membrane association of AR, eliminated AR membrane translocation under testosterone, and prevented AR nuclear trafficking. These findings suggest that kinase Src is involved in the mechanism of AR trafficking that induced by testosterone.

The activation of the kinases by non-genomic action in Sertoli cells led to testosteroneinduced AR nuclear translocation. This finding indicates a possible correlation between 


\section{Cellular Physiology Cell Physiol Biochem 2017;43:223-236 \\ \begin{tabular}{ll|l} 
DOI: 10.1159/000480343 29,2017 & $\begin{array}{l}\text { O 2017 The Author(s). Published by S. Karger AG, Basel } \\
\text { www.karger.com/cpb }\end{array}$
\end{tabular} \\ Deng et al.: Phosphorylation Signaling Pathway Mediated AR Trafficking}

the classical genomic pathway and the non-classical pathway: the non-genomic androgen actions resulted in the regulation of AR-mediated nuclear (genomic) gene transcriptional repression or activation.

As in murine Sertoli cells, we postulated a possible androgen action pathway in Fig. 9. Androgen (T) diffused into cytoplasm, bound to AR and induced AR translocation to nucleus. $\mathrm{T}$ could also associate with membrane AR, then the receptor interacts with and activates Src kinase. Once activated, Src caused EGFR via an intracellular pathway, which resulted in activation of the kinases RAF, MEK, and Erk. This non-genomic pathway had been well reported by Walk's group [1], and our study verify the pathway.

Akt is an important downstream target of PI3K (phosphatidylinositol 3-kinase) [38]. AR could direct interact with PI3K regulatory subunit p85 $\alpha$ [39] to activate PI3K. PI3K has been shown to be an important effector of Ras [40], Ras could interact with PI3K catalytic subunit $\mathrm{p} 110 \beta$. Catalytic subunits $\mathrm{p} 110 \beta$ and $\mathrm{p} 110 \alpha$ were reported to have an important role in male reproduction. Src may modulate the interaction of AR with Akt [39]. And PI3K/ AKT signaling pathway could also activate MEK/Erk cascade, which was regulate by PTEN (Phosphatase and tensin homolog deleted on chromosome 10) [41]. This activation of MEK and Akt phosphorylation signaling pathway then promoted the activation of the kinase Src, which is considered a scaffold protein of the AR complex. After being phosphorylated, the AR was translocated to the membrane to retain phosphorylation signaling; more ARs were translocated to the nucleus to induce gene transcriptional activation or repression.

\section{Conclusion}

Testosterone is required for processes that are critical for spermatogenesis, including maintaining the BTB, supporting the completion of meiosis, adhesion of elongated spermatids to Sertoli cells, and release of sperm. These processes require the synergistic actions of the classical and the non-classical signaling pathways. In this study, we found that physiological testosterone concentration induced the membrane association of the classical AR. This association was mediated by the MEK and the Akt phosphorylation signaling pathways, which resulted in the activation of kinase Src and was initiated by testosterone binding to the membrane localized AR. This study directly provides that the non-classical action can regulate the classical pathway. This study can enrich the mechanism of the androgen actions and provide new insights into the testosterone signaling pathway in Sertoli cells, which mediate spermatogenesis. This study can also be used in diagnose and treatment of male infertility caused disorders in spermatogenesis. Further studies need to be conducted to elucidate the precise mechanism of the phosphorylation signaling pathway initiated by testosterone associated with membrane AR.

\section{Acknowledgements}

The author(s) disclosed receipt of the following financial support for the research, authorship, and/or publication of this article: This work was supported by Grants from National Natural Science Foundation of China (31471344, 31271244), China Postdoctoral Science Foundation (2016M590798), Natural Science Foundation of Guangdong Province, China (2016A030310071), the Knowledge and Innovation Planning Project of Shenzhen Municipality, China (JCY2144905865), the Science and Technology Planning Project of Shenzhen Municipality, China (JCY20130402113131202, JCYJ20140415162543017, JCYJ20160428171238706) and the Health and Family Planning Commission Project of Shenzhen Municipality, China (201605017).

\section{Disclosure Statement}

The author(s) declared no potential conflicts of interest with respect to the research, authorship, and/or publication of this article. 


\section{Cellular Physiology Cell Physiol Biochem 2017;43:223-236 \begin{tabular}{l|l|l} 
and Biochemistry Publisned onIIne: August 29, 2017 & $\begin{array}{l}\text { (c) } 2017 \text { The Author(s). Published by S. Karger AG, Basel } \\
\text { www.karger.com/cpb }\end{array}$
\end{tabular}

\section{References}

1 Smith LB, Walker WH: The regulation of spermatogenesis by androgens. Semin Cell Dev Biol 2014;30:2-13.

2 Chang C, Chen YT, Yeh SD, Xu Q, Wang RS, Guillou F, Lardy H, Yeh S: Infertility with defective spermatogenesis and hypotestosteronemia in male mice lacking the androgen receptor in Sertoli cells. Proc Natl Acad Sci U S A 2004;101:6876-6881.

3 De Gendt K, Swinnen JV, Saunders PT, Schoonjans L, Dewerchin M, Devos A, Tan K, Atanassova N, Claessens F, Lecureuil C, Heyns W, Carmeliet P, Guillou F, Sharpe RM, Verhoeven G: A Sertoli cell-selective knockout of the androgen receptor causes spermatogenic arrest in meiosis. Proc Natl Acad Sci U S A 2004;101:13271332.

-4 Wang RS, Yeh S, Chen LM, Lin HY, Zhang C, Ni J, Wu CC, di Sant'Agnese PA, deMesy-Bentley KL, Tzeng $\mathrm{CR}$, Chang C: Androgen receptor in sertoli cell is essential for germ cell nursery and junctional complex formation in mouse testes. Endocrinology 2006;147:5624-5633.

5 Tsai MY, Yeh SD, Wang RS, Yeh S, Zhang C, Lin HY, Tzeng CR, Chang C: Differential effects of spermatogenesis and fertility in mice lacking androgen receptor in individual testis cells. Proc Natl Acad Sci U S A 2006;103:18975-18980.

-6 Chen SR, Hao XX, Zhang Y, Deng SL, Wang ZP, Wang YQ, Wang XX, Liu YX: Androgen receptor in Sertoli cells regulates DNA double-strand break repair and chromosomal synapsis of spermatocytes partially through intercellular EGF-EGFR signaling. Oncotarget 2016;7:18722-18735.

7 Kurowicka B, Chrusciel M, Zmijewska A, Doroszko M, Kotwica G, Rahman NA: Distinct testicular steroidogenic response mechanisms between neonatal and adult heat-acclimated male rats. Cell Physiol Biochem 2015;35:1729-1743.

8 Tsai MJ, O'Malley BW: Molecular mechanisms of action of steroid/thyroid receptor superfamily members. Annu Rev Biochem 1994;63:451-486.

-9 Li JC, Mruk D, Cheng CY: The inter-Sertoli tight junction permeability barrier is regulated by the interplay of protein phosphatases and kinases: an in vitro study. J Androl 2001;22:847-856.

10 Siu MK, Wong CH, Lee WM, Cheng CY: Sertoli-germ cell anchoring junction dynamics in the testis are regulated by an interplay of lipid and protein kinases. J Biol Chem 2005;280:25029-25047.

11 Wong CH, Cheng CY: Mitogen-activated protein kinases, adherens junction dynamics, and spermatogenesis: a review of recent data. Dev Biol 2005;286:1-15.

12 Shupe J, Cheng J, Puri P, Kostereva N, Walker WH: Regulation of Sertoli-germ cell adhesion and sperm release by FSH and nonclassical testosterone signaling. Mol Endocrinol 2011;25:238-252.

13 Cheng J, Watkins SC, Walker WH: Testosterone activates mitogen-activated protein kinase via Src kinase and the epidermal growth factor receptor in sertoli cells. Endocrinology 2007;148:2066-2074.

14 Scobey M, Bertera S, Somers J, Watkins S, Zeleznik A, Walker W: Delivery of a cyclic adenosine 3',5'-monophosphate response element-binding protein (creb) mutant to seminiferous tubules results in impaired spermatogenesis. Endocrinology 2001;142:948-954.

15 Toocheck C, Clister T, Shupe J, Crum C, Ravindranathan P, Lee TK, Ahn JM, Raj GV, Sukhwani M, Orwig KE, Walker WH: Mouse Spermatogenesis Requires Classical and Nonclassical Testosterone Signaling. Biol Reprod 2016;94:11.

16 Hua SY, Chen YZ: Membrane receptor-mediated electrophysiological effects of glucocorticoid on mammalian neurons. Endocrinology 1989;124:687-691.

17 Razandi M, Pedram A, Greene GL, Levin ER: Cell membrane and nuclear estrogen receptors (ERs) originate from a single transcript: studies of ERalpha and ERbeta expressed in Chinese hamster ovary cells. Mol Endocrinol 1999;13:307-319.

18 Song RX, McPherson RA, Adam L, Bao Y, Shupnik M, Kumar R, Santen RJ: Linkage of rapid estrogen action to MAPK activation by ERalpha-Shc association and Shc pathway activation. Mol Endocrinol 2002;16:116127.

19 Razandi M, Pedram A, Park ST, Levin ER: Proximal events in signaling by plasma membrane estrogen receptors. J Biol Chem 2003;278:2701-2712.

20 El-Hefnawy T, Manna PR, Luconi M, Baldi E, Slotte JP, Huhtaniemi I: Progesterone action in a murine Leydig tumor cell line (mLTC-1), possibly through a nonclassical receptor type. Endocrinology 2000;141:247-255.

21 Peluso JJ, Fernandez G, Pappalardo A, White BA: Characterization of a putative membrane receptor for progesterone in rat granulosa cells. Biol Reprod 2001;65:94-101. 


\section{Cellular Physiology Cell Physiol Biochem 2017;43:223-236 \begin{tabular}{ll|l} 
DOI: 10.1159/000480343 29, 2017 & $\begin{array}{l}\text { O 2017 The Author(s). Published by S. Karger AG, Basel } \\
\text { www.karger.com/cpb }\end{array}$ \\
and Biochemistry Publisned online: August 29.
\end{tabular}

22 Deng Q, Riquelme D, Trinh L, Low MJ, Tomic M, Stojilkovic S, Aguilera G: Rapid Glucocorticoid Feedback Inhibition of ACTH Secretion Involves Ligand-Dependent Membrane Association of Glucocorticoid Receptors. Endocrinology 2015;156:3215-3227.

23 Griswold MD: The central role of Sertoli cells in spermatogenesis. Semin Cell Dev Biol 1998;9:411-416.

24 Shang Y, Myers M, Brown M: Formation of the androgen receptor transcription complex. Mol Cell 2002;9:601-610.

25 Fix C, Jordan C, Cano P, Walker WH: Testosterone activates mitogen-activated protein kinase and the cAMP response element binding protein transcription factor in Sertoli cells. Proc Natl Acad Sci U S A 2004;101:10919-10924.

-26 Migliaccio A, Castoria G, Di Domenico M, de Falco A, Bilancio A, Lombardi M, Barone MV, Ametrano D, Zannini MS, Abbondanza C, Auricchio F: Steroid-induced androgen receptor-oestradiol receptor beta-Src complex triggers prostate cancer cell proliferation. EMBO J 2000;19:5406-5417.

-27 Kousteni S, Bellido T, Plotkin LI, O’Brien CA, Bodenner DL, Han L, Han K, DiGregorio GB, Katzenellenbogen JA, Katzenellenbogen BS, Roberson PK, Weinstein RS, Jilka RL, Manolagas SC: Nongenotropic, sexnonspecific signaling through the estrogen or androgen receptors: dissociation from transcriptional activity. Cell 2001;104:719-730.

28 Wong CW, McNally C, Nickbarg E, Komm BS, Cheskis BJ: Estrogen receptor-interacting protein that modulates its nongenomic activity-crosstalk with Src/Erk phosphorylation cascade. Proc Natl Acad Sci U S A 2002;99:14783-14788.

29 Unni E, Sun S, Nan B, McPhaul MJ, Cheskis B, Mancini MA, Marcelli M: Changes in androgen receptor nongenotropic signaling correlate with transition of LNCaP cells to androgen independence. Cancer Res 2004;64:7156-7168.

-30 Zhang J, Wong CH, Xia W, Mruk DD, Lee NP, Lee WM, Cheng CY: Regulation of Sertoli-germ cell adherens junction dynamics via changes in protein-protein interactions of the $\mathrm{N}$-cadherin-beta-catenin protein complex which are possibly mediated by c-Src and myotubularin-related protein 2: an in vivo study using an androgen suppression model. Endocrinology 2005;146:1268-1284.

-31 Wang W, Wine RN, Chapin RE: Rat testicular Src: normal distribution and involvement in ethylene glycol monomethyl ether-induced apoptosis. Toxicol Appl Pharmacol 2000;163:125-134.

-32 Chapin RE, Wine RN, Harris MW, Borchers CH, Haseman JK: Structure and control of a cell-cell adhesion complex associated with spermiation in rat seminiferous epithelium. J Androl 2001;22:1030-1052.

33 Kinch MS, Clark GJ, Der CJ, Burridge K: Tyrosine phosphorylation regulates the adhesions of rastransformed breast epithelia. J Cell Biol 1995;130:461-471.

-34 Roura S, Miravet S, Piedra J, Garcia de Herreros A, Dunach M: Regulation of E-cadherin/Catenin association by tyrosine phosphorylation. J Biol Chem 1999;274:36734-36740.

-35 Xia W, Cheng CY: TGF-beta3 regulates anchoring junction dynamics in the seminiferous epithelium of the rat testis via the Ras/ERK signaling pathway: An in vivo study. Dev Biol 2005;280:321-343.

-36 Gu S, Honisch S, Kounenidakis M, Alkahtani S, Alarifi S, Alevizopoulos K, Stournaras C, Lang F: Membrane androgen receptor down-regulates c-src-activity and beta-catenin transcription and triggers GSK-3betaphosphorylation in colon tumor cells. Cell Physiol Biochem 2014;34:1402-1412.

-37 Szafran AT, Stephan C, Bolt M, Mancini MG, Marcelli M, Mancini MA: High-Content Screening Identifies Src Family Kinases as Potential Regulators of AR-V7 Expression and Androgen-Independent Cell Growth. Prostate 2016;10.1002/pros.23251

-38 Manning BD, Cantley LC: AKT/PKB signaling: navigating downstream. Cell 2007;129:1261-1274.

-39 Sun M, Yang L, Feldman RI, Sun XM, Bhalla KN, Jove R, Nicosia SV, Cheng JQ: Activation of phosphatidylinositol 3-kinase/Akt pathway by androgen through interaction of p85alpha, androgen receptor, and Src. J Biol Chem 2003;278:42992-43000.

40 Downward J: Targeting RAS signalling pathways in cancer therapy. Nat Rev Cancer 2003;3:11-22.

41 Carnero A, Paramio JM: The PTEN/PI3K/AKT Pathway in vivo, Cancer Mouse Models. Front Oncol $2014 ; 4: 252$. 